\title{
Experimental Determination of the Global Mass Transfer Coefficients of the Tropical Woods in order to Deduce the Drying Curves at the Lower Temperature
}

\author{
Merlin Simo-Tagne $^{\mathrm{a}, \mathrm{b}, *}$, Louis Monkam ${ }^{\mathrm{c}}$, Romain Rémond ${ }^{\mathrm{d}}$, André Zoulalian ${ }^{\mathrm{e}}$, Yann Rogaume ${ }^{\mathrm{d}}$, \\ Beguidé Bonoma ${ }^{a}$ \\ ${ }^{a}$ University of Yaoundé I, Higher Teacher Training College, Applied Physic Laboratory, PO Box 47, Yaoundé, \\ Cameroon \\ ${ }^{b}$ Douala Institute of Technology (DIT), PO Box 1623, Douala, Cameroon \\ ${ }^{c}$ University of Douala, Energy Laboratory of the Doctorate School of Physics and Engineering Sciences, PO Box 8698 , \\ Douala, Cameroon \\ ${ }^{d}$ University of Lorraine, LERMAB, ENSTIB, 27 rue Philippe Séguin, PO Box 1041, F-88051 Epinal, France \\ ${ }^{e}$ University of Lorraine, LERMAB, Faculty of Sciences and Technologies - Aiguillettes Campus- PO Box 70239 - 54506 \\ Vandoeuvre les Nancy Cedex, Nancy, France
}

\section{Abstract}

We determine the global mass transfer coefficients of five tropical woods (obeche, iroko, lotofa, sapele and frake) coming from Cameroon. In this effect, drying kinetics using a solar dryer and a conventional dryer are utilized. In addition, comparison is doing between the values obtained and these coming from Chileans tropical woods and temperate. Thus, when the drying kinetics are between 0.25 to $1.5 \mathrm{~m} / \mathrm{s}$, dry temperature equal to $33.5^{\circ} \mathrm{C}$ and wet temperature equal to $25^{\circ} \mathrm{C}$, global mass transfer coefficients are between $2 \times 10^{-5}$ and $4 \times 10^{-5} \mathrm{~kg} /\left(\mathrm{m}^{2} . \mathrm{s}\right)$, for the conventional dryer. These values are conform to these obtained on the Chilean tropical woods and less than these obtained on the temperate woods. In the case of an indirect solar dryer functioning between October and November 2004 at Yaoundé, this coefficient is lower because the wood thickness is almost $24 \mathrm{~mm}$ in the case of conventional drying and 50mm in the case of solar drying. It is coherent to use the correlation established with the temperate wood and given below where the parameters $a_{0}, b_{0}, c_{o}$ and $p$ should be specific on the tropical woods:

$$
\frac{1}{\mathrm{~K}}=\mathrm{a}_{\mathrm{o}} \exp \left(\frac{\mathrm{c}_{\mathrm{o}}}{\mathrm{T}_{\mathrm{a}}}\right) \mathrm{e}+\mathrm{b}_{\mathrm{o}} \exp \left(\frac{\mathrm{c}_{\mathrm{o}}}{\mathrm{T}_{\mathrm{a}}}\right) \mathrm{V}^{-\mathrm{p}} \exp \left(-\frac{1-\frac{\mathrm{RH}}{100}}{\mathrm{X}_{\mathrm{fsp}}-\mathrm{X}_{\mathrm{eq}}}\right)
$$

Keywords: Global mass transfer coefficients, Drying kinetics, Tropical woods, Conventional dryer, Solar dryer, Experiment, Modeling, Cameroon.

\section{Introduction}

The wood exploitation contributes significantly to the financial expansion of the tropical countries. For the case of Cameroon, the wood is after the petroleum the product most exported in the form of volume and the selling price. Also, the interior marker

${ }^{*}$ Corresponding author. Tel.: 00(237) 694852402

E-mail: Author. simotagne2002@yahoo.fr

(C) 2016 International Association for Sharing Knowledge and Sustainability

DOI: $10.5383 /$ ijtee.12.01.002 is satisfied in this sense that wood is used such as woodengraving and it is always used in the building construction. The Environment Forest Sectorial Program (PSFE) is a tool given by the Cameroon in order to maintenance his forest patrimony and to ratify the international exigencies. It is estimated that the $70 \%$ of the volume of wood which enter in the Cameroonian sawmills are lost in the form of wood waste, without forgetter that the middle of the tree is also deserted in the forest [1]. The decree 
$\mathrm{n}^{\circ} 99 / 781 / \mathrm{PM}$ of the $13^{\text {th }}$ October 1999 imposes an interdiction to export thirteen wood species from Cameroon in the form of rough imber. We can cite by example bubinga, doussié, fromager, illonga, iroko, moabi, padouk, sapele and wengé. Thus, it is an uncontested importance to develop the chemical and thermophysical knowledge wood collected in order to ameliorate theirs methods of conservation such as the conventional and solar drying, then to optimize the maintenance of the forest biologic products.

It is true that the characterization of the wood is most diffused in the literature, but the results are not generalize at all tropical woods because the differences observed at the microscopic scale between temperate and those tropical, and same between the same type of wood [2]. The knowledge of the mass diffusion coefficients of the biological materials permits to estimate their drying times and given the possibilities to optimize consummation of the energy during the drying process and to offer possibilities to multiply the techniques of the drying in the view of the technological valorization of wood. Also, the study of the thermal comfort of the building made in wood is ease. In this paper, we determine experimentally the global mass transfer coefficients of five tropical woods come from Cameroon: ayous, sapele, iroko, lotofa and fraké. This coefficient is determined in the literature on the hêtre, épicéa and coïgue woods [3-6].

\section{Material and Methods}

\subsection{Conventional Drying}

Immediately at the end of the drying, we have extracted two samples at $2 \mathrm{~cm}$ of thickness by species in the length way, each sample is localized at $10 \mathrm{~cm}$ from each extremity. Afterwards, each sample has been identified, weighing and introduced in the oven regular at $103^{\circ} \mathrm{C}$ in order to determine, after $24 \mathrm{~h}$ of drying time, the dried mass of each sample [7]. The averages of the two water content obtained by species permit to have the final water content by species and to deduce the dried mass of each utilized board. For each species, the following relation is utilized to determine the dry mass of the board:

$X_{f}=\frac{x_{f 1}+X_{f 2}}{2}$

$M_{0}=\frac{100 M_{f}}{X_{f}+100}$

With $\mathrm{M}_{\mathrm{f}}$ the last measured mass of the board immediately before extracted in the oven and $\mathrm{M}_{0}$ the dry mass of the board. Anatomical directions and dimensions of the samples are given in table 1. Figures 1 and 2 below present the dryer and the samples in the dryer. Figure 3 presents the oven utilized to give anhydrous ours samples. Figure 4 presents the dry and wet temperatures utilized.
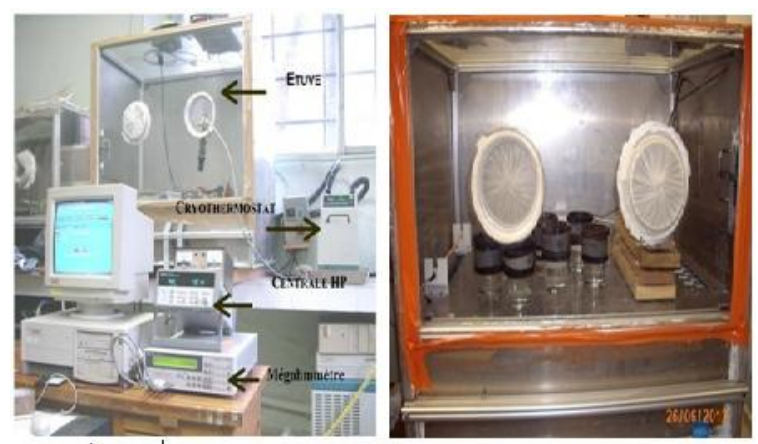

Fig. 1. Equipment and dryer at the controlled atmosphere
Table 1. Description of the boards samples, conventional drying

\begin{tabular}{|c|c|c|c|}
\hline Species & Lxlxe $(\mathrm{cm})$ & $\begin{array}{c}\text { Annual } \\
\text { growth rings }\end{array}$ & $\begin{array}{c}\text { Anatomical } \\
\text { direction }\end{array}$ \\
\hline Ayous & $36.5 \times 11.7 \times 2.5$ & Flatsawn & Radial \\
\hline Fraké & $43 \times 10.8 \times 2.4$ & Quartersawn & Tangential \\
\hline Sapele & $43 \times 8.8 \times 2.2$ & Quartersawn & Tangential \\
\hline Lotofa & $43 \times 7 \times 2.4$ & Quartersawn & Tangential \\
\hline
\end{tabular}

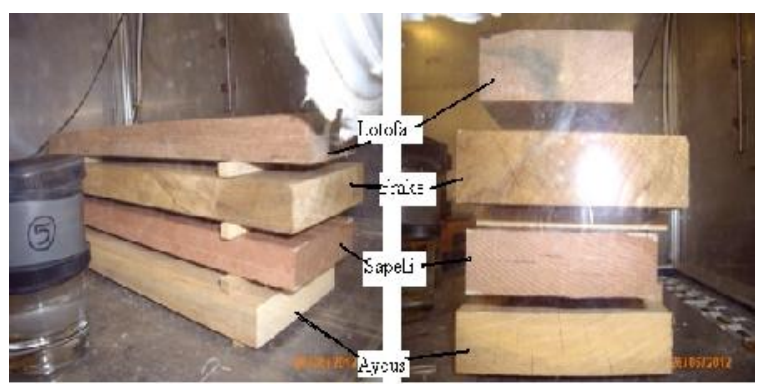

Fig. 2. Disposition of the board during the study of the drying kinetic with constant atmosphere

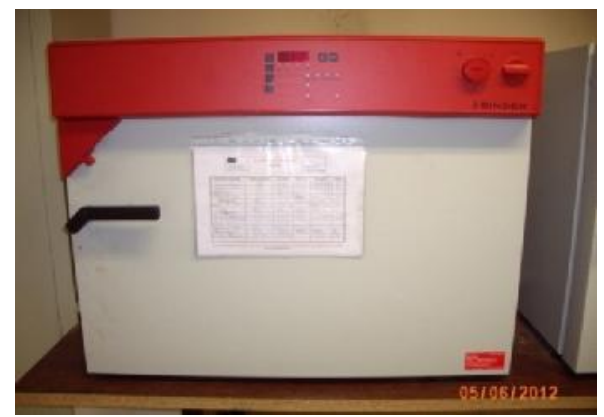

Fig. 3. Oven utilized

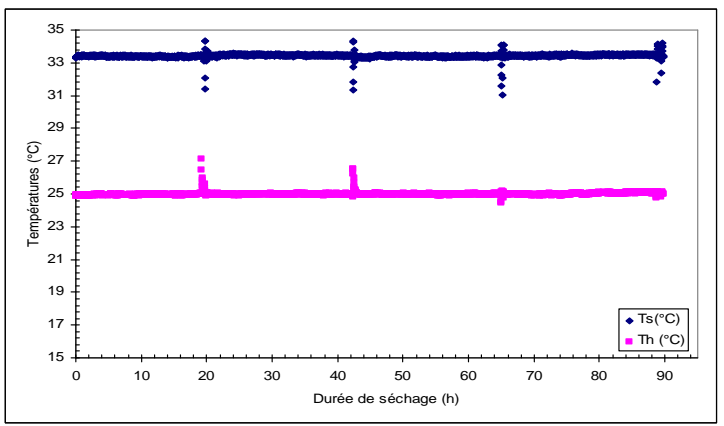

Fig. 4. Dry temperature $\left(T_{s}\right)$ and wet temperature $\left(T_{h}\right)$ utilized during the drying at constant atmosphere

\subsection{Solar drying}

Solar dryer utilized is presented on the figure 5 below. The walls are made in polyethylene. The dryer is used in the town of Yaoundé-Cameroon from October to November 2004 for the case of ayous and sapele, from November to December 2004 for the case of iroko. Table 2 presents the boards utilized here.

Table 2. Description of the boards samples, solar drying

\begin{tabular}{|c|c|c|c|}
\hline Species & Lxlxe $(\mathrm{cm})$ & $\begin{array}{c}\text { Annual } \\
\text { growth rings }\end{array}$ & $\begin{array}{c}\text { Anatomical } \\
\text { direction }\end{array}$ \\
\hline Ayous & $5 \times 35 \times 220$ & Quartersawn & Tangential \\
\hline Iroko & $5 \times 40 \times 210$ & Quartersawn & Tangential \\
\hline Sapele & $5 \times 35 \times 220$ & Quartersawn & Tangential \\
\hline
\end{tabular}




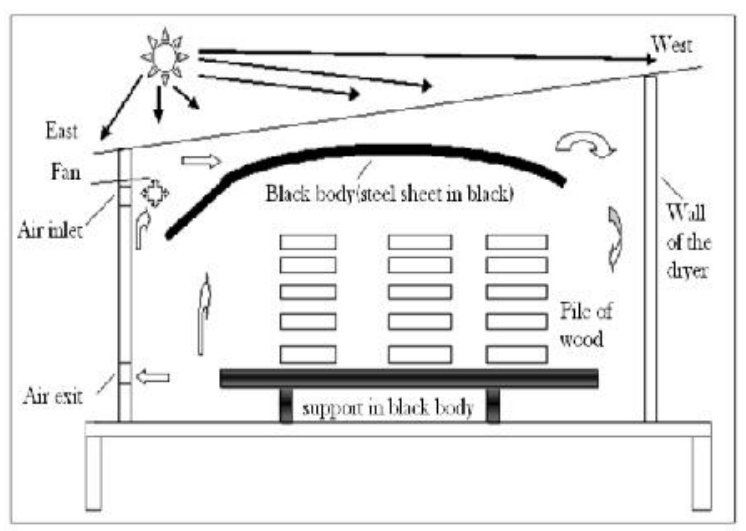

Fig. 5. Indirect solar dryer used. Capacity: $4 \mathrm{~m}^{3}$; air velocity: $1.5 \mathrm{~m} / \mathrm{s}$

\subsection{Methods}

We focused to the drying points where the temperature of board becomes constant. When this phase becomes, relation 3 is verified where $\mathrm{X}$ is the water content, $\mathrm{X}_{\mathrm{eq}}$ the equilibrium water content, $S$ the surface of the transfer of humidity, $t$ the drying time, $M_{\circ}$ is the dry mass of the board and $\mathrm{K}$ the global mass transfer coefficient.

$$
-\mathrm{M}_{0} \frac{\mathrm{dX}}{\mathrm{dt}}=\mathrm{KS}\left(\mathrm{X}-\mathrm{X}_{\mathrm{eq}}\right)
$$

Thus, we suppose that $\mathrm{K}$ is constant in the space and in the time, we obtain relation 4 where $t_{t}$ is the time where the temperature of the board becomes to be constant from the start of the drying, $\mathrm{X}_{\mathrm{t}}$ is the water content of the board at the drying time $\mathrm{t}_{\mathrm{t}}$.

$-\mathrm{LN}\left(\frac{\mathrm{X}-\mathrm{X}_{\mathrm{eq}}}{\mathrm{X}_{\mathrm{t}}-\mathrm{X}_{\mathrm{eq}}}\right)=\frac{K S}{M_{\mathrm{o}}} \mathrm{t}(\mathrm{h})-\frac{K S}{M_{\mathrm{o}}} \mathrm{t}_{\mathrm{t}}(\mathrm{h})$

Thus, the plot of the function $-\mathrm{LN}\left(\frac{\mathrm{x}-\mathrm{x}_{\mathrm{eq}}}{\mathrm{x}_{\mathrm{t}}-\mathrm{x}_{\mathrm{eq}}}\right)=\mathrm{f}(\mathrm{t})$ permits to deduce the researched parameter $\mathrm{K}$ which is function of the thermophysical conditions of the drying air, in addition of the wood characteristics. When researched parameters are founded, the drying kinetic is plotted using relation 5.

$X=X_{\text {eq }}+\left(X_{t}-X_{\text {eq }}\right) \exp \left(-\frac{K S}{M_{0}}\left(t-t_{t}\right)\right)$

The validation of the correlation is obtained using the square of the correlation coefficient $\mathrm{R}^{2}$ and the relative difference given by the relation 6 .

$\mathrm{E}(\%)=\frac{100}{\mathrm{~N}} \sum_{\mathrm{i}=1}^{\mathrm{N}} \frac{\left|\mathrm{X}_{\text {exper }_{\mathrm{i}}}-\mathrm{X}_{\text {theor }_{\mathrm{i}}}\right|}{\mathrm{X}_{\text {exper }_{\mathrm{i}}}}$

Where $X_{\text {exper }}$ and $X_{\text {theor }}$ are the water content obtained experimentally and by the relation 6 respectively. $\mathrm{N}$ is the number of experimental points.

\section{Results and Discussion}

\subsection{Conventional drying}

Figure 6 below presents the obtained experimental curves.

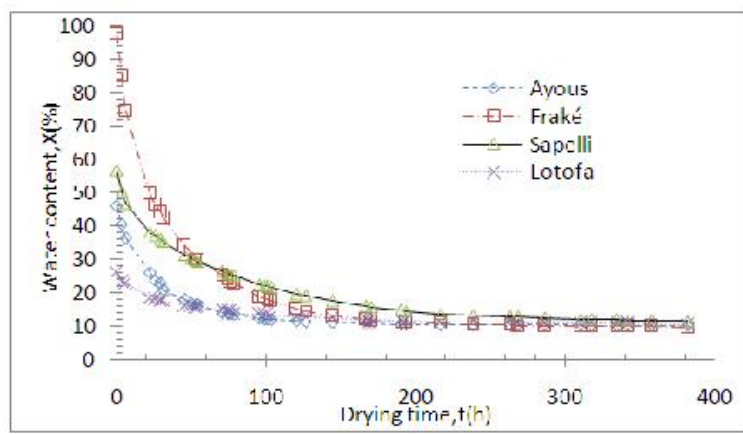

Fig.6. Experimental water content evolutions versus drying time.

The plotting the curve $-\mathrm{LN}\left(\frac{\mathrm{x}-\mathrm{X}_{\mathrm{eq}}}{\mathrm{x}_{\mathrm{t}}-\mathrm{X}_{\mathrm{eq}}}\right)=\mathrm{f}(\mathrm{t})$ presented at the figure 7 permits to present the transition phase. We have taken the space ranged between $20 \mathrm{~h}$ and $125 \mathrm{~h}$ of the drying

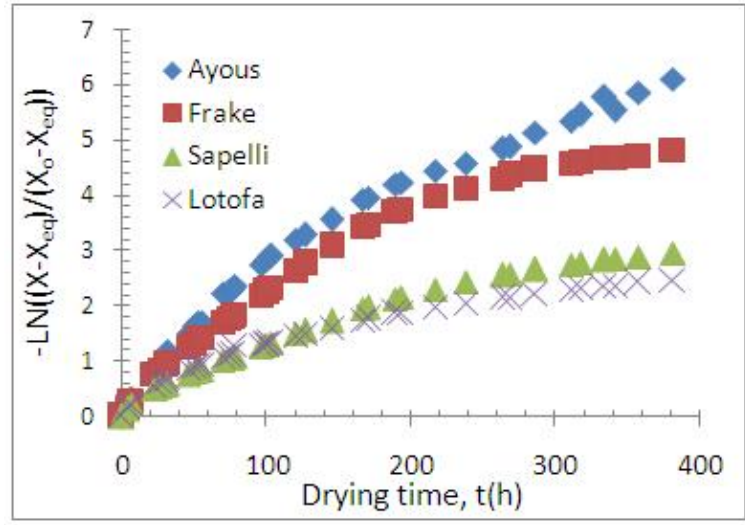

(a) Evolution on all drying time

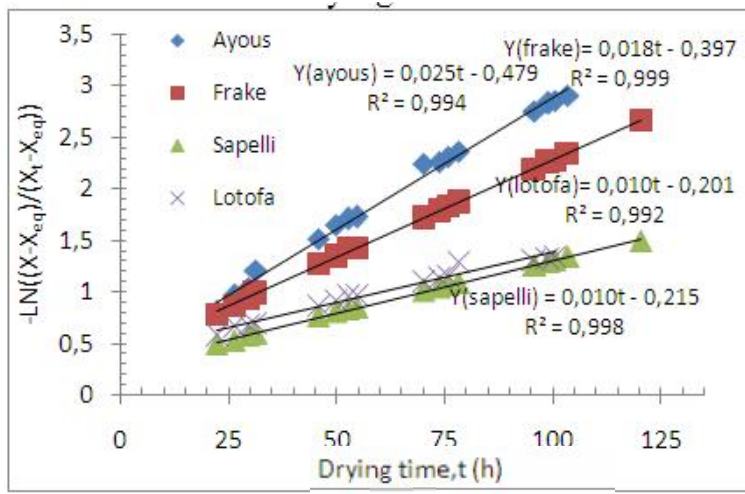

(b) Evolution between $20 \mathrm{~h}$ and $125 \mathrm{~h}$ of the drying Fig.7. $-L N\left(\frac{X-X_{e q}}{x_{t}-X_{e q}}\right)=f(t)$

Table 3 presents the parameters of ours woods obtained. The relations 7 present the equations obtained with different square of correlation with the values are satisfactory and validate the chosen method.

Table 4 presents the obtained global mass transfer coefficients with the differences when only experimental points after the stabilization of the temperature are confronted $\left(\mathrm{E}_{1}(\%)\right)$ and when all the drying time is used $\left(\mathrm{E}_{2}(\%)\right)$. 
Table 3. Obtained parameters, Conventional drying

\begin{tabular}{|c|c|c|c|c|}
\hline Parameters & Ayous & Lotofa & Sapele & Frake \\
\hline $\mathrm{M}_{\mathrm{i}}(\mathrm{g})$ & 696.6 & 622.73 & 849.14 & 1048.25 \\
\hline $\mathrm{M}_{\mathrm{o}}(\mathrm{g})$ & 475.386 & 494.575 & 541.798 & 530.727 \\
\hline $\mathrm{S}_{\mathrm{b}}=2 \mathrm{~S}_{\mathrm{b} 1}\left(\mathrm{~cm}^{2}\right)$ & 854.1 & 602 & 746.8 & 928.8 \\
\hline $\mathrm{X}_{\mathrm{o}}(\%)$ & 45.90 & 25.91 & 56.73 & 97.51 \\
\hline $\mathrm{X}_{\mathrm{t}}(\%)$ & 25.9 & 18.54 & 38.13 & 49.49 \\
\hline $\mathrm{X}_{\mathrm{eq}}(\%)$ & 10 & 10 & 10 & 10 \\
\hline $\mathrm{X}_{\text {first }}(\%)$ & 12.07 & 13.43 & 19.04 & 14.55 \\
\hline
\end{tabular}

Ayous: $-\ln \left(\frac{X-X_{\overline{e q}}}{X_{t}-X_{\text {eq }}}\right)=0.025 t(h)-0.47 ; R^{2}=0.994$

Frake: $-\ln \left(\frac{\mathrm{X}-\mathrm{X}_{\mathrm{eq}}}{\mathrm{x}_{\mathrm{t}}-\mathrm{X}_{\mathrm{eq}}}\right)=0.018 \mathrm{t}(\mathrm{h})-0.3 ; \mathrm{R}^{2}=0.999$

Lotofa: $-\ln \left(\frac{\mathrm{x}-\mathrm{x}_{\mathrm{eq}}}{\mathrm{X}_{\mathrm{t}}-\mathrm{X}_{\mathrm{eq}}}\right)=0.010 \mathrm{t}(\mathrm{h})-0.20 ; \mathrm{R}^{2}=0.992$

Sapele: $-\ln \left(\frac{X-X_{\text {eq }}}{X_{\mathrm{t}}-X_{\text {eq }}}\right)=0.010 t(h)-0.215 ; R^{2}=0.998$
Table 4. Obtained global mass transfers, Conventional drying

\begin{tabular}{|c|c|c|c|c|}
\hline Parameters & Ayous & Lotofa & Sapele & Frake \\
\hline $\mathrm{t}_{\mathrm{t}}(\mathrm{h})$ & 19.16 & 20.10 & 21.50 & 22.06 \\
\hline $\begin{array}{c}\mathrm{K} \mathrm{x} 10^{5} \\
\left(\mathrm{~kg} /\left(\mathrm{m}^{2} . \mathrm{s}\right)\right)\end{array}$ & 3.865 & 2.282 & 2.015 & 2.857 \\
\hline $\mathrm{E}_{1}(\%)$ & 2.065 & 2.276 & 3.308 & 5.744 \\
\hline $\mathrm{E}_{2}(\%)$ & 3.272 & 3.343 & 4.201 & 7.126 \\
\hline
\end{tabular}

Table 6. Global mass transfer coefficients and drying conditions of some wood species during conventional drying [4]

\begin{tabular}{|c|c|c|c|c|c|}
\hline $\begin{array}{c}\text { Wood } \\
\text { Species }\end{array}$ & $\begin{array}{c}\mathrm{e} \\
\mathrm{mm}\end{array}$ & $\begin{array}{c}\mathrm{T} \\
{ }^{\circ} \mathrm{C}\end{array}$ & $\begin{array}{c}\mathrm{T}_{\mathrm{w}} \\
{ }^{\circ} \mathrm{C}\end{array}$ & $\begin{array}{c}\mathrm{v} \\
\mathrm{m} / \mathrm{s}\end{array}$ & $\begin{array}{c}\mathrm{K} .10^{5} \\
\mathrm{~kg} /\left(\mathrm{m}^{2} . \mathrm{s}\right)\end{array}$ \\
\hline Spruce & 18 & 70 & 50 & 3 & 12.5 \\
\hline Spruce & 27 & 70 & 50 & 3 & 7.48 \\
\hline Spruce & 41 & 70 & 50 & 3 & 6.39 \\
\hline Beech & 30 & 70 & 50 & 2 & 5.21 \\
\hline Beech & 30 & 70 & 50 & 5 & 7.81 \\
\hline Coigüe & 38 & 60 & 44 & 2.5 & 0.43 \\
\hline
\end{tabular}

Table 5. Global mass transfer coefficients and drying conditions of the Chilean coigüe Nothofagus dombeyi during conventional drying [3]

\begin{tabular}{|c|c|c|c|c|c|c|c|c|c|c|c|}
\hline \multirow[t]{2}{*}{ Cycle } & \multicolumn{6}{|c|}{ Constants } & \multicolumn{4}{|c|}{$\begin{array}{c}\text { Variables } \\
\text { (Initial Values) }\end{array}$} & $\begin{array}{c}\text { Global } \\
\text { Coefficients }\end{array}$ \\
\hline & $\begin{array}{c}\mathrm{G} \\
\mathrm{kg} \cdot \mathrm{s}^{-1}\end{array}$ & $\begin{array}{l}\mathrm{e} \\
\mathrm{m}\end{array}$ & $\begin{array}{c}\mathrm{S} \\
\mathrm{m}^{2}\end{array}$ & $\begin{array}{c}\mathrm{M}_{\mathrm{B}} \\
\mathrm{kg}\end{array}$ & $\begin{array}{l}\mathrm{T}_{\text {in }} \\
{ }^{\circ} \mathrm{C}\end{array}$ & $\begin{array}{c}\mathrm{W}_{\text {in }} \\
\mathrm{kg} \cdot \mathrm{kg}^{-1}\end{array}$ & $\begin{array}{c}\mathrm{MC} \\
\% \\
\end{array}$ & $\begin{array}{c}\text { Wout }_{\text {out }} \\
\mathrm{kg} \cdot \mathrm{kg}^{-1}\end{array}$ & $\begin{array}{l}\text { Tout } \\
{ }^{\circ} \mathrm{C}\end{array}$ & $\begin{array}{l}\mathrm{T}_{\mathrm{w}} \\
{ }^{\circ} \mathrm{C}\end{array}$ & $\begin{array}{c}\mathrm{K} \cdot 10^{5} \\
\mathrm{~kg} \cdot \mathrm{m}^{-2} \cdot \mathrm{s}^{-2}\end{array}$ \\
\hline 1 & 0.3037 & 0.0184 & 10.6 & 50.6 & 65 & 0.0359 & 107.5 & 0.0359 & 60 & 52 & 3.37 \\
\hline 2 & 0.6116 & 0.0217 & 11.5 & 61.1 & 64 & 0.0359 & 104.1 & 0.0359 & 60 & 17 & 3.18 \\
\hline 3 & 0.3058 & 0.0296 & 12.0 & 83.3 & 67 & 0.0530 & 107.7 & 0.0531 & 58 & 47 & 2.06 \\
\hline 4 & 0.6116 & 0.0308 & 12.4 & 87.5 & 66 & 0.0474 & 107.5 & 0.0474 & 62 & 35 & 1.87 \\
\hline
\end{tabular}

It is clear that experimental points are most defined when wood temperature is stabilized. Additionally, global mass transfer coefficients are higher when the density is lower. It is difficult to connect the duration of the stabilization of wood temperature and the density of ours woods, but it is clear that this duration is localized between 19 and 22h of drying. Tables 5 and 6 show that Chilean tropical wood (coïgue) have the global mass transfer coefficients near of ours studied woods, the drying temperatures used by the authors are almost the double of ours temperatures and the thickness are between 18 and $38 \mathrm{~mm}$.

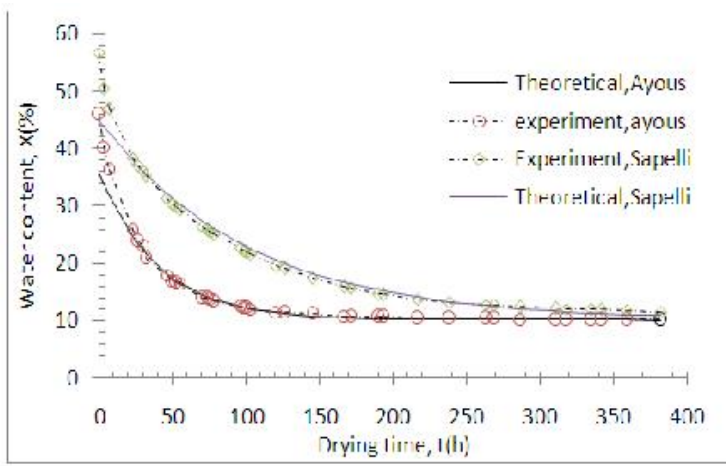

Fig.8. Experimental and theoretical curves of ayous and sapele

It is clear to recall that ours samples have an averaged thickness equal to $24 \mathrm{~mm}$. to look at the cycles of the table 5 , we constant that the wood thickness has an important influence on the global mass transfer coefficients. Table 6 shows that global mass transfer coefficients of the temperate woods will be superior at the double of those of the tropical woods, showing that the drying of the tropical woods are very lower than temperate woods. Figures 8 and 9 show the evolutions of theoretical and experimental drying kinetics of ours woods. we constant à good representation of the experimental curves after the drying time where the temperature is stabilized, but also after $125 \mathrm{~h}$ of the drying which is the superior limit used to estimate the global mass transfer coefficients.

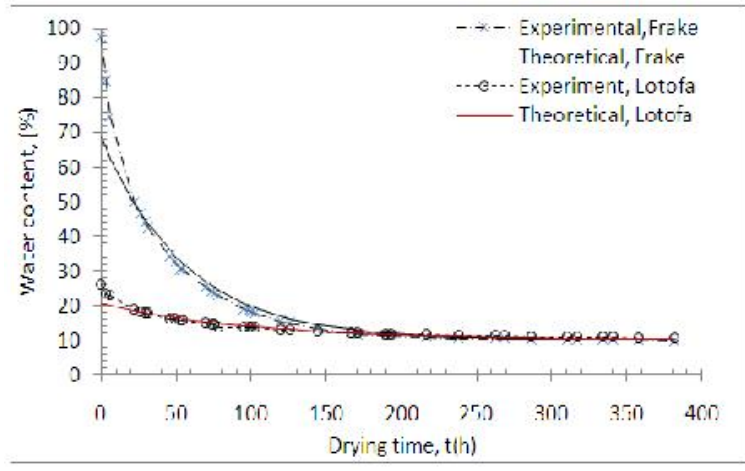

Fig.9. Experimental and theoretical curves of fraké and lotofa

\subsection{Solar Drying}

In the case of solar drying, the characteristics of the air are function of the day, month and the hour of the day $[8,9]$. The ones are variables and give irregular variations of the drying 
kinetic. The view of the experimental curves permit us to distinguish many fragments in the case of ayous and sapele. In the case of iroko only one curve satisfied the description of experimental points. The relations 8,9 and 10 permit us to traduce experimental kinetics. Squares correlation coefficients values show that this method is adapted. Figures 10,11 and 12 present the experimental kinetics of the studied woods. It is clear that theoretical curves explained so good experimental curves. Ayous:

$$
\begin{aligned}
& t \leq 264 h,-\ln \left(\frac{X-X_{e q}}{X_{0}-X_{e q}}\right)=0.004 t(h), R^{2}=0.993 \\
& t \geq 264 h,-\ln \left(\frac{x-X_{e q}}{X_{0}-X_{e q}}\right)=0.013(t(h)-185.15) ; R^{2}=0.95
\end{aligned}
$$

Sapele:

$t \leq 360 h,-\ln \left(\frac{X-X_{e q}}{X_{0}-X_{e q}}\right)=0.002 t(h), R^{2}=0.985$

$t \geq 360 h,-\ln \left(\frac{X-X_{e q}}{X_{0}-X_{e q}}\right)=0.018\left(t(h)-327.17, R^{2}=0.913\right.$

Iroko :

$\forall t \geq 0 ;-\ln \left(\frac{X-X_{e q}}{X_{0}-X_{e q}}\right)=0.006 t(h), R^{2}=0.982$

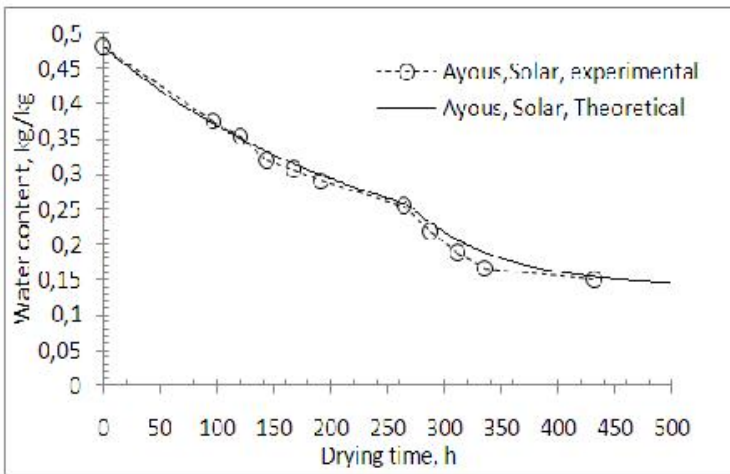

Fig .10. Solar drying kinetic of ayous, from $29^{\text {th }}$ October to $15^{\text {th }}$ November 2004 at Yaoundé-Cameroon

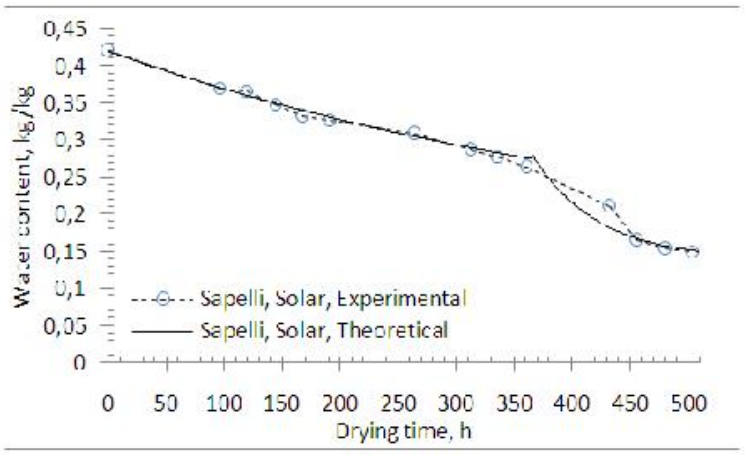

Fig. 11. Solar drying kinetic of sapele, from $29^{\text {th }}$ October to $18^{\text {th }}$ November 2004 at Yaoundé-Cameroon

Table 7 presents the masses (anhydrous and initial) of the samples, the relative differences and the obtained global mass transfer coefficients. We note that the presence of many fragments on the curves are caused by the new stability of the wood temperature each time that the temperature of the air ambient changes. In the case of iroko, global mass transfer coefficient is equal to $1.1033 \times 10^{-5} \mathrm{~kg} /\left(\mathrm{m}^{2} . \mathrm{s}\right)$, in the same order than the conventional drying. After $360 \mathrm{~h}$, global mass transfer coefficient of sapele is also in the order of $10^{-5} \mathrm{~kg} /\left(\mathrm{m}^{2} . \mathrm{s}\right)$. Before $360 \mathrm{~h}$ of the drying, this coefficient is in the order of $10^{-6}$ $\mathrm{kg} /\left(\mathrm{m}^{2} . \mathrm{s}\right)$, such as in the case of ayous during all the drying time. Difference obtained between solar and conventional drying can be caused by the thickness of the board. In effect, according to the literature, global mass transfer coefficient decreases when thickness increases [5,6]. Because the air conditions between solar and conventional drying used are near, it is possible that the global mass transfer coefficient is lower in the case of solar drying caused by the thickness of the board which is almost the double of the thickness of board used in the case of conventional drying.

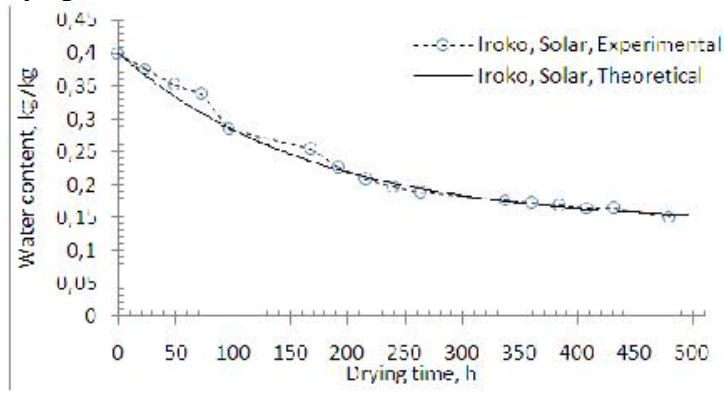

Fig.12. Solar drying kinetic of iroko, from $22^{\text {th }}$ November to $12^{\text {th }}$ December 2004 at Yaoundé-Cameroon

\begin{tabular}{|c|c|c|c|c|c|}
\hline \multirow[t]{2}{*}{ Parameters } & \multicolumn{2}{|c|}{ Ayous } & \multicolumn{2}{|c|}{ Sapele } & Iroko \\
\hline & $\begin{array}{l}\text { nimed } \\
t \bar{t}\end{array}$ & 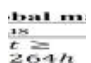 & 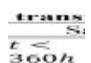 & 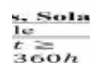 & 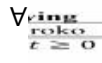 \\
\hline Temp & \multirow{2}{*}{\multicolumn{2}{|c|}{$\begin{array}{l}50 \leq \frac{\geq}{64 h} \\
\leq 65{ }_{C}{ }_{C}\end{array}$}} & \multirow{2}{*}{\multicolumn{2}{|c|}{$\begin{array}{l}50 \leq \quad 80 h \\
\leq 65^{c}{ }_{C}^{c}\end{array}$}} & $50 \geq$ \\
\hline e & & & & & $\begin{array}{l}\leq T \\
\leq 65^{6}\end{array}$ \\
\hline $\mathrm{M}_{\mathrm{i}}(\mathrm{k}$ & \multicolumn{2}{|c|}{5.024} & \multicolumn{2}{|c|}{13.83} & 15.75 \\
\hline $\mathrm{M}_{\mathrm{o}}(\mathrm{k}$ & \multicolumn{2}{|c|}{3.3947} & \multicolumn{2}{|c|}{9.7394} & 11.121 \\
\hline $\mathrm{Kx}$ & 2.449 & 7.960 & 3.513 & 31.62 & 11.033 \\
\hline$\left(\mathrm{kg} /\left(\mathrm{m}^{2} . \mathrm{s}\right.\right.$ & 5 & 9 & 5 & 2 & \\
\hline $\mathrm{E}(\%)$ & \multicolumn{2}{|c|}{4.0492} & \multicolumn{2}{|c|}{2.2756} & 2.7548 \\
\hline
\end{tabular}

Table 7. Obtained global mass transfers, Solar drying

To correlate the global mass transfer coefficient in function of the parameters of the wood and the drying air, the authors $[5,6]$ have established relation 11 where the parameters $a_{o}, b_{o}, c_{o}$ and $\mathrm{p}$ are to determine in function of wood species.

$\frac{1}{K}=a_{o} \exp \left(\frac{c_{o}}{T_{a}}\right) e+b_{o} \exp \left(\frac{c_{o}}{T_{a}}\right) V^{-p} \exp \left(-\frac{1-\frac{R H}{100}}{x_{f s p}-X_{e q}}\right)$

$\mathrm{K}$ is the global mass transfer coefficient $\left(\mathrm{kg} /\left(\mathrm{m}^{2} . \mathrm{s}\right)\right), \mathrm{T}_{\mathrm{a}}$ is air temperature in Kelvin, V is air velocity $(\mathrm{m} / \mathrm{s}), \mathrm{RH}$ is air relative humidity in $\%, \mathrm{X}_{\mathrm{fsp}}$ and $\mathrm{X}_{\mathrm{eq}}$ are the water content respectively in the fiber saturation point and in equilibrium state in decimal, $\mathrm{e}$ is the thickness of the board in $\mathrm{m}$.

Applied on temperate woods, the authors $[5,6]$ obtained the parameters $a_{o}, b_{o}, c_{o}$ and $p$ given on the table 8 .

Table 8. Parameters of equation 11 given on the literature

\begin{tabular}{|c|c|c|}
\hline Parameters & {$[5]$} & {$[6]$} \\
\hline $\mathrm{a}_{\mathrm{o}}(\mathrm{ms} / \mathrm{kg})$ & 0.12 & 0.2265 \\
\hline $\mathrm{c}_{\mathrm{o}}(\mathrm{K})$ & 23.9 & 268.9 \\
\hline $\mathrm{p}(-)$ & 2683 & 2543.6 \\
\hline & 0.8 & 2.7158 \\
\hline
\end{tabular}

It is very important to determine the same parameters on tropical woods in order to obtain the specificities own of the drying of tropical woods and simulate very well the drying of these woods in the future using relations 5 and 11 which are very simple to use, comparative of the other modeling such as [10]. 


\section{Conclusion}

1. Simplified method is appropriated to describe the drying kinetics of Cameroonian tropical woods. But, it is necessary to use the phase where wood temperature becomes constant in the case of conventional drying;

2. Global mass transfer coefficients of tropical woods studied are in the same order than Chilean woods. these are between $2 \times 10^{-5}$ et $4 \times 10^{-5} \mathrm{~kg} /\left(\mathrm{m}^{2} . \mathrm{s}\right)$ when dryer is conventional with air kinetic is between 0.25 and $1.5 \mathrm{~m} / \mathrm{s}$, the thickness of board is between 24 and $30 \mathrm{~mm}$, dry temperature equal to $33.5^{\circ} \mathrm{C}$ and wet temperature is equal to $25^{\circ} \mathrm{C}$. For solar drying at Yaoundé from October to December with $50 \mathrm{~mm}$ of thickness, this coefficient is lower than those obtained on conventional drying with $25 \mathrm{~mm}$ of thickness;

3. Global mass transfer coefficient decreases when density of wood increases. This coefficient decreases when increases the thickness of board;

4. In general, global mass transfer coefficients obtained are less important than those obtained on temperate woods in the same air and board conditions;

5. A specific study in function of the influence of thermophysical conditions of wood and drying air on the global mass transfer coefficients of African tropical woods is important in order to have the appropriated results in the situation of the variations of air conditions during the drying process such as those used in the industrial reality and in the solar drying process. Thus, determination of the parameters $\mathrm{a}_{\mathrm{o}}, \mathrm{b}_{\mathrm{o}}, \mathrm{c}_{\mathrm{o}}$ and $\mathrm{p}$ of equation 11 using tropical wood is necessary.

\section{Acknowledgments}

This work is a part of the Post Doctorate research done by principal author and funded by the International Tropical Timber Organization (ITTO). Principal author wishes to acknowledge this International Organization. Additionally, he gratefully acknowledges Mr. Tristan STEIN, the Technician of LERMaB, University of Lorraine-France, for the sampling collection of ours woods and the setting of apparatus measures.

I want to thank Pr. Melo born Uphie F. CHINJE, the Director of the Mission of Promotion of the Local Materials (MIPROMALO) of Cameroon for the permission to use experimental results on solar drying obtained from the laboratory of her structure.

Also, I wish that Mr. Pierre HAGUE of the sawmill SEEF.SA situated at Douala-Cameroon receives my great thanks for providing the wood species required for this research.

\section{References}

[1] GTZ. Note technique sur le bois énergie au Cameroun. 2006.

[2] M. Simo-Tagne. Experimental characterization of the influence of water content on the density and shrinkage of tropical woods coming from Cameroon and deduction of their fiber saturation points. IJSR 2014. 3 (6): 510-515.

[3] Alvear M, Broche W, Salinas C, Ananias R.A. Drying kinetic of Chilean coigüe: study of the global drying coefficient. $8^{\text {th }}$ International IUFRO Wood Drying Conference. 383-387, 2003.

[4] Ananias, R.A., Chrusciel, L., Zoulalian, A., SalinasLira, C., Mougel, E: Overall Mass Transfer moefficient for wood drying curves predictions, mass transfer in multiphase systems and its applications. Prof. Mohamed El-Amin (Ed.), ISBN: 978-953-307215-9, InTech, Available from: http://www.intechopen.com/books/mass-transfer-inmultiphase-systems-and-its-applications/overallmasstransfer-coefficient-for-wood-drying-curvespredictions, 2011.

[5] R. A. Ananías, E. Mougel, A. Zoulalian. Introducing an overall mass-transfer coefficient for prediction of drying curves at low temperature drying rates. Wood Science and Technology 2009. 43: (1): 43-56.

[6] L. Chrusciel, E. Mougel, A. Zoulalian, T. Meunier. Characterisation of water transfer in a low temperature convective wood drier: influence of the operating parameters on the mass transfer coefficient. Holz Roh Werkstoff 1999. (57):439-445.

[7] Norme française. Bois- Conditions générales d'essaisEssais Physiques et Mécaniques. 1985.

[8] N. Bekkioui, A. Zoulalian, A. Hakam, F. Bentayeb, A. Sesbou. Modelling of a solar wood dryer with glazed walls. Maderas Ciencia y Tecnologia 2009. (11) 3:191-205.

[9] F. Bentayeb, N. Bekkioui, B. Zeghmati. Modelling and simulation of a wood solar dryer in a Moroccan climate. Renewable Energy 2008. (33):501-506. DOI: 10.1016/j.renene.2007.03.030

[10] M. Simo-Tagne. Laboratory simulation of solar drying for tropical woods: the case of ebony (diospyros crassiflora). International Journal of Thermal and Environment Engineering 2015. 9 (1):1-6. DOI: 10.5383/ijtee.09.01.001. 